\title{
Managerial Competences in International Scope
}

\author{
Karolina Ławicka \\ Faculty of Economics \\ Maria Curie-Sktodorwsk University in Lublin, Poland \\ karolina.lawicka@poczta.umcs.lublin.pl \\ Agnieszka Sitko-Lutek \\ Faculty of Economics \\ Maria Curie-Sktodowska University in Lublin, Poland \\ agnieszka.sitko-lutek@poczta.umcs.lublin.pl
}

\begin{abstract}
Purpose - The aim of the paper is an identification of key managerial competences based on selected typologies described in the literature of the subject and studies reflecting managerial practices in East-Central Europe (Slovakia, Lithuania, Poland).

Design/Methodology/Approach - The present study constitutes a review of the Polish and international literature of the subject.

Findings - Fifteen key managerial competences were selected on the basis of managerial competences' typologies outlined in the literature. Practitioners participating in several studies acknowledged the competences to be significant in managers' work. They were also indicated as crucial in managers' work by practitioners who had taken part in the described research survey. The most important were: personality traits such as flexibility, interpersonal/social skills, leadership, teamwork, and decision-making. Moreover, apart from the set of competences featured in the literature, evaluated mangers indicated two additional competences: information gathering and change management, which they considered vital.

Originality/Value - The paper is a comparison of the international observations with findings of studies encompassing managers from three European states: Lithuania, Slovakia, and Poland.
\end{abstract}

Keywords - management, competences, managerial competences, competence models, managers' skills.

\section{Introduction}

ICT advancements, global information, product and people flow, constant national and global changes, constitute only a few of determinants impacting modern economies and daily challenges for organizations. Managers who plan, decide, organize, manage and supervise all resources in organizations constitute a key driving force for prosperity and development of enterprises. As a consequence, they ought to act effectively (Penc, 2005, pp. 323-324).

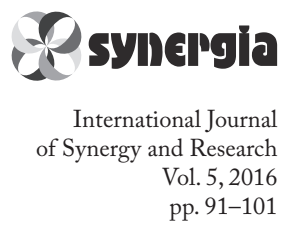


IJSR 5

The significance and gravity of managers' responsibilities result in considerable interest in the issue of managers' key competences determining success and efficiency of their actions.

The aim of the paper is to analyse and identify key managerial competences on the basis of the chosen typologies contained in the literature of the subject as well as on studies conducted among practitioners of East-Central Europe. The analysis was based on studies made in Lithuania, Slovakia, and Poland - in the countries which in the past belonged to the Eastern Bloc where socialism hindered social life and economic growth. Economic transformation in these countries took place almost 30 years ago. Then, in 2004, they joined the EU. Disproportions between the mentioned countries and countries with longer free market economy history have been evened out. Therefore, the selection of the surveys was made upon a similar history of countries' economies conducted therein, neighbouring geographical location, and slight discrepancy in the social, economic, and cultural spheres.

To sum up, the goal of the paper is to identify key managerial competences based on the selected literature and researches.

\section{Modern typologies of managerial competences}

The literature of the subject offers various definitions of the term "competences". For the purpose of the present study, the definition offered by Rakowska (2007) was assumed. The definition establishes that competences of modern managers are: personal features, application of knowledge (qualifications, experiences), attitude, and skills (Rakowska, 2007, p. 149).

The following authors described typologies of competences: The following authors described typologies of competences: Rakowska (2007), Chełpa (2003), Kuc (2003 after: Rakowska, 2007, p. 72), Walkowiak (2004), Penc (2005), Kubik (2005), Nawrat (2013), as well as Peterson and Van Fleet (2004 after: Rakowska, 2007, p. 68), Caprioni (2004 after: Rakowska, 2007, p. 72), Viitala (2005, after: Springer, 2013, p. 198), Dainty (2005, after: Gholipur, 2012, p. 508) and Boyatzis (2011). The present paper focuses on five of them.

The first typology of interest was described by Abraham et al. (2001, pp. 842-852). The author enumerated 10 critical competences: flexibility/adaptation, interpersonal skills, focus on clients, teamwork, verbal and written communication, problem-solving, leadership, credibility, focus on objectives, and pursuit of quality (Bakanauskienè and Martinkienè, 2011, p. 31).

The second typology, offered by Kubik (2005), classifies competences into 7groups: education, fluency in languages, skills: interpersonal, conceptual, technical, diagnostic, and analytic. In addition, the author makes a reference to opinions of psychologists who observe that managers' effectiveness is determined by certain features of their personality which boost a success factor in the field. Some of these are included in Table 1 (Kubik, 2005, pp. 85-86).

Another interesting typology which views competences in light of psychology and intelligence in a broad sense, was developed by Boyatzis (2011). The following groups $^{1}$ emerged in the process of categorization (Boyatzis, 2011, p. 94):

1 Literally: clusters. 
- Self-awareness - the ability to recognize one's own internal states, preferences, resources, intuitions. It encompasses one competence: emotional self-awareness i.e. recognizing one's own emotions and their impact;

- Emotional self-awareness - refers to the management of internal impulses and resources; competences: emotional self-control, adaptation, focus on objectives, positive mind-set (optimistic attitude);

- Social awareness - empathy and organizational awareness;

- Relationships' management - coaching and mentoring, inspiring leadership, influencing others, conflict management, teamwork;

- Competences associated with cognitive intelligence i.e. systemic thinking and recognition of patterns.

Another typology, presented by Dainty (2005), consists of 11 points: leadership, making relationships, team-building, teamwork, focus on objectives, personal development, planning, efficiency, sales focus, decision-making, focus on clients (Gholipur et al., 2012, p. 508).

Filipowicz (2016) developed an interesting, systematized competence model. It is based on cases of approx. 200 organizations which implemented competence systems. Competence map (a term developed by the team) was designed as a result of an analysis pertaining to competences featured in job descriptions and organizations' sets of competences. The map encompassed 36 most frequently indicated vocational competences. The author does not perceive the set as final. However, it is considered that in $90 \%$ of companies, the set is sufficient for introducing a Competence Management System. The author established 9 managerial competences among these (Filipowicz, 2016, p. 101).

- Social competences: building relations, knowledge and experience sharing, identification with the company, communication, negotiation, focus on clients, teamwork, problem solving, intra-organizational cooperation;

- Personal competences: pursuit of objectives (resourcefulness), innovation and flexibility, analytical thinking, self-reliance, decision-making, problem-solving, conscientiousness/reliability, professional development/willingness to learn, selfmanagement;

- Managerial competences: developing efficient organization, teambuilding, evaluation and development of subordinates (coaching), delegating, motivating, strategic thinking, planning, leadership, team management;

- Vocational competences: administration/managing document flow, orientation in business procedures - familiarity and application, IT skills, technical skills, vocational knowledge, project management, process management, foreign languages proficiency.

Based on the outlined typologies, key managerial competences were collected in Table 1.

In accordance with the above collection, 15 categories of managerial competences can be isolated:

1. Knowledge, experience, vocational and technical skills

2. Personality 
Pobrane z czasopisma International Journal of Synergy and Research http://ijsr.journals.umcs.pl

Data: 26/04/2023 11:27:17

94

\section{IJSR}

5

\begin{tabular}{|c|c|c|c|c|c|}
\hline $\begin{array}{l}\text { Abraham et al. } \\
\text { (2001) }\end{array}$ & $\begin{array}{l}\text { Boyatzis } \\
\text { (2011) }\end{array}$ & $\begin{array}{l}\text { Kubik } \\
(2005)\end{array}$ & $\begin{array}{l}\text { Dainty } \\
(2005)\end{array}$ & $\begin{array}{l}\text { Filipowicz } \\
\text { (2016) }\end{array}$ & Conclusions \\
\hline & & $\begin{array}{l}\text { education, foreign } \\
\text { languages, technical } \\
\text { skills }\end{array}$ & & $\begin{array}{l}\text { administration, } \\
\text { familiarity with } \\
\text { procedures, IT } \\
\text { skills, technical } \\
\text { skills, vocational } \\
\text { knowledge, foreign } \\
\text { languages }\end{array}$ & $\begin{array}{l}\text { knowledge, } \\
\text { experience, } \\
\text { vocational and } \\
\text { technical skills }\end{array}$ \\
\hline \multirow[t]{2}{*}{$\begin{array}{l}\text { flexibility/ } \\
\text { adaptation }\end{array}$} & $\begin{array}{l}\text { emotional } \\
\text { self-awareness, } \\
\text { emotional } \\
\text { self-control, } \\
\text { adaptability, focus } \\
\text { on objectives, } \\
\text { optimistic attitude }\end{array}$ & $\begin{array}{l}\text { e.g. activity, } \\
\text { flexibility, honesty, } \\
\text { swift decision- } \\
\text { making, social } \\
\text { maturity, self-control, } \\
\text { inclination towards } \\
\text { improvement }\end{array}$ & efficiency & $\begin{array}{l}\text { resourcefulness, } \\
\text { innovation and } \\
\text { flexibility, analytical } \\
\text { thinking, self-reliance, } \\
\text { conscientiousness, }\end{array}$ & personality \\
\hline & $\begin{array}{l}\text { (as a personality } \\
\text { feature) }\end{array}$ & & $\begin{array}{l}\text { self- } \\
\text { development }\end{array}$ & $\begin{array}{l}\text { vocational } \\
\text { development, self- } \\
\text { management }\end{array}$ & $\begin{array}{l}\text { self- } \\
\text { development }\end{array}$ \\
\hline $\begin{array}{l}\text { interpersonal } \\
\text { skills }\end{array}$ & $\begin{array}{l}\text { social awareness: } \\
\text { empathy, } \\
\text { organizational } \\
\text { awareness }\end{array}$ & interpersonal skills & $\begin{array}{l}\text { establishing } \\
\text { relationships }\end{array}$ & $\begin{array}{l}\text { development of } \\
\text { relations, knowledge } \\
\text { and experience } \\
\text { sharing, }\end{array}$ & $\begin{array}{l}\text { interpersonal/ } \\
\text { social }\end{array}$ \\
\hline focus on clients & & & $\begin{array}{l}\text { focus on } \\
\text { clients }\end{array}$ & focus on clients & $\begin{array}{l}\text { focus on } \\
\text { clients }\end{array}$ \\
\hline teamwork & teamwork & & teamwork & $\begin{array}{l}\text { teamwork, inter- } \\
\text { company cooperation, }\end{array}$ & teamwork \\
\hline $\begin{array}{l}\text { verbal and } \\
\text { written } \\
\text { communication }\end{array}$ & influencing others & & & $\begin{array}{l}\text { communication, } \\
\text { negotiation }\end{array}$ & communication \\
\hline problem solving & & $\begin{array}{l}\text { (as a personality } \\
\text { feature) }\end{array}$ & $\begin{array}{l}\text { decision- } \\
\text { making }\end{array}$ & $\begin{array}{l}\text { decision-making, } \\
\text { problem-solving }\end{array}$ & $\begin{array}{l}\text { decision- } \\
\text { making }\end{array}$ \\
\hline \multirow[t]{4}{*}{ leadership } & leadership & & leadership & leadership & leadership \\
\hline & $\begin{array}{l}\text { coaching and } \\
\text { mentoring }\end{array}$ & & teambuilding & $\begin{array}{l}\text { team-building, } \\
\text { evaluation and } \\
\text { development of } \\
\text { subordinates, team } \\
\text { management }\end{array}$ & teambuilding \\
\hline & $\begin{array}{l}\text { conflict } \\
\text { management }\end{array}$ & & & conflict solving & conflict solving \\
\hline & & conceptual skills & planning & $\begin{array}{l}\text { developing efficient } \\
\text { organization, } \\
\text { delegating, planning }\end{array}$ & $\begin{array}{l}\text { planning and } \\
\text { coordination of } \\
\text { activities }\end{array}$ \\
\hline
\end{tabular}

Table1.

A set of key managerial competences based on the selected typologies. 


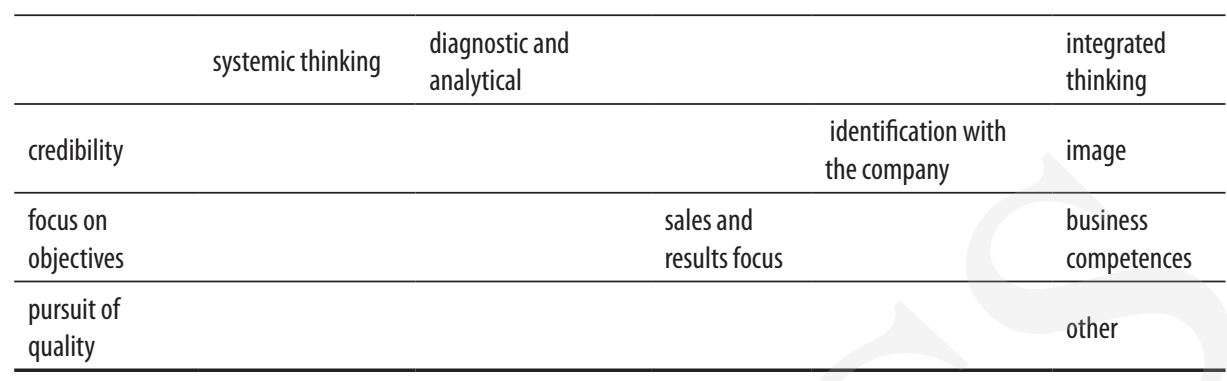

Source: Authors' own study on the basis of the literature: Abraham et al. (2001), Kubik (2005), Boyatzis

(2011), Dainty (2005), Filipowicz (2016).

3. Self-development

4. Interpersonal/social

5. Focus on clients

6. Teamwork

7. Communication

8. Decision-making

9. Leadership

10. Teambuilding

11. Conflict solving

12. Planning and coordination of activities

13. Integrated thinking

14. Image

15. Business competences

A premise must be made that the categorization was made for methodological purposes. A clear and distinct classification is virtually impossible. There exist relations between individual competences, thus, it is difficult to separate e.g. communication from teambuilding.

\section{Key managerial competences in studies}

In 2011, in Lithuania, a study titled Determining Managerial Competencies of Management Professionals by Bakanauskienè and Martinkienė (2011) was published. The aim of the study was to determine and define managerial competences on the basis of a survey conducted among managers of companies in western Lithuania. The following research methods were applied: analysis of the hitherto studies, a questionnaire, and qualitative and quantitative surveys. The study was conducted among mid-level management. Eleven surveys were collected from managers of 11 different companies. The following structure of businesses emerged: 5 industrial companies (46\%), 2 trade companies (18\%), 2 service companies (18\%), and 2 international companies (18\%). Managers' professional experience was the following: 1 had 3-5 years' experience (9\%), 1 - 5-7 (9\%), 2 - 7-10 (18\%), 2 - 13-15 (18\%), 1 - 15-18 (9\%), and 3-18-20 (18\%). Each of respondents possessed a university degree (at least a Bachelor's). Fifty nine competences in 3 subgroups were presented to respondents. The subgroups were 
IJSR 5

the following: professional/managerial (29), social (16), and personal (14). Based on this study, it may be observed that, according to respondents, key competences in their positions include: striving for results, communication, convincing communications, responsibility, and learning from one's own and others' experience. In addition, the following scored further on the list: fairness, self-development, and orientation to customer. The list ended with conflict handling, ethics, and self-trust (Bakanauskiené and Martinkienè, 2011, pp. 29-43).

A study in Slovakia was conducted in parallel (2010-2011). It encompassed 73 managers representing 46 companies from Slovakia (78\%), and other EU states: the Czech Republic (7\%), Belgium (4\%), Denmark (3\%), Great Britain (3\%), France $(1.25 \%)$, Poland $(1.25 \%)$, Austria $(1.25 \%)$, and Italy (1.25\%). Managers' professional experience was the following: $47 \%$ - below 5 years' experience, $45 \%-5-15$ years, and $8 \%$ above 15 years. The study evaluated managers' soft competences. An online or paper questionnaire (depending on respondents' preferences) was applied to conduct the survey. The survey question was the following: "Are you motivated to use identified competences at your workplace?". To sum up the studies, respondents believe that the following skills and features motivate them at work: flexibility $(86 \%)$, analytical skills $(84 \%)$, respecting others $(82 \%)$ collective problem solving $(81 \%)$, driving organizational change (79\%), active listening (78\%), feedback (77\%), ethical behaviour, support (77\%) and client focus (75\%). Moreover, more than $60 \%$ indicated the following as significant: empathy (73\%), empowering (70\%), respecting other cultures (68\%), diversity support (64\%), emphasis an awareness (63\%), openness to information (62\%) and self-development focus (60\%) (Sajgalikova et al., 2012, pp. 944-952).

Another interesting study in the field of managerial competences, titled Managerial Competencies and Innovations in the Company - the Case of Enterprises in Poland, was published in 2014 by Szczepańska-Woszczyna and Dacko-Pikiewicz. The authors explore the subject of competences in light of innovation implementation in companies, because, as they observed, the emphasis has been recently placed upon human capital and competences facilitating innovative processes (Szczepańska-Woszczyna and Dacko-Pikiewicz, 2014, pp. 266-282).

In modern global economy, constant technological advancements, free transfer of products, and multitude of business entities, development of competitive advantages determine organizations' survival. According to Limański, "factors facilitating the development of competitive advantages include: access to resources critical for success in a particular sector, and possession and ability for constant creation of skills, knowledge, innovation, creation and dissemination of novel solutions". Moreover, the author observes that innovation, as a characteristic feature of organizations, if detached from integrated and coordinated activities in all aspects of the company's operations, will not overcome existing flaws and weaknesses (Limański, 2011, p. 146).

Therefore, implementation of innovations in modern businesses ought to become a standard procedure in organizations' day-to-day operations, which determines their survival. This, in turn, ought to be based upon a key determinant for implementing such a change, i.e. competent managers, and introducing integrated actions. As a consequence, the above mentioned study was included in the present paper. 
The study was conducted among top-, middle- and operational-level managers of Silesian companies. Results were obtained on the basis of 101 questionnaires. Respondents' structure was approximately the following: $23.7 \%$ were 40 years of age and older, $48.5 \%$ were $31-40,27.5 \%$ were younger than 31 . Moreover, $97 \%$ of respondents graduated with a university degree. $43.6 \%$ of them graduated from studies in economics, 20.8\% - engineering, 14.9\% - humanities and social sciences, $11.9 \%$ - law and administration. In addition, $20 \%$ of managers had over 10 years' experience in this position, $18.9 \%-5-10$ years, and the remaining -5 years. The questionnaire consisted of 10 questions with a Likert-type scale (score 5 indicating "maximum agreement" and 1 "no agreement"), and closed single-choice questions. Apart from demographics, the questionnaire featured a question on the type and scope of innovations introduced in the company. In $66.6 \%$ of cases, technological innovations were implemented, in $58.4 \%$ product innovations, in 56.4\% - organizational innovations, and in $43.6 \%$ - marketing innovations. In $11.9 \%$ of companies innovations were international in scope, in $19.8 \%$ the scope was national. The remaining ones pertained to a region, sector or company.

Individual elements of competences such as knowledge, skills, features and attitudes were presented by means of a list and divided into six sections: 1) knowledge, 2) analytical, conceptual, 3) interpersonal skills, 4) personal skills, 5) managerial competences, 6) features, attitudes and behaviour. Szczepańska-Woszczyna and DackoPikiewicz (2014) presented results for 60 elements.

Managers responded in questionnaires considered the following 18 competences as the most sought for: operational and strategic thinking, knowledge of the industry, striving to achieve results, coping with change, analytical skills, activity and initiative, setting goals, motivating others, and managerial courage. The following are of significance as well: commitment, creative problem solving, ability to develop employees' commitment, observing the market and competitors, openness to change, motivating others (as an interpersonal skill), ability to listen, accept orders and having the vision and implementing it (Szczepańska-Woszczyna and Dacko-Pikiewicz, 2014, pp. 266-282).

\section{Conclusions}

As far as the main aim of the present study is concerned, it revolved around the identification of modern managerial competences' typologies described in the literature of the subject with studies examining managerial practice of East-Central Europe. Considering the first column on the left-hand side in Table 2 - it contains a list of key managerial competences compiled on the basis of the selected typologies: Abraham et al.'s (2001), Kubik's (2005), Boyatzis' (2011), Dainty's (2005), and Filipowicz's (2016). The remaining columns encompass competences indicated by respondents of the subsequent studies.

Authors of the outlined literature of the subject offer various numbers of competences in their typologies, which was determined by their significance for managers. However, authors unanimously mention some of the areas: personality features, and interpersonal/ social skills. As far as the first group is concerned, they were not unanimous with regards to individual personality features or behaviours. However, all of them acknowledged

\author{
Managerial \\ Competences \\ in International \\ Scope
}


IJSR 5

personality as vital for managers. In addition, 3 out of 5 authors indicated flexibility as a significant feature. Next, they acknowledge that leadership, teamwork and decisionmaking are crucial as well. Four out of five authors allotted separate categories for these in their typologies. Self-development, focus on clients, communication, teambuilding, and planning and coordinating are seen as important as well. The authors differed the most in their opinions on knowledge, experience, vocational and technical skills, problem-solving, integrated thinking, image, and business skills associated with focus on results and sales.

On the other hand, respondents were unanimous in the opinion that the following constitute critical competences for managers: integrated thinking (operational, analytical, strategic), information gathering/openness to information, and similar to typologies described in the literature - personality features. In the latter case, respondents indicated flexibility, ethical behaviour, activity, initiative, and responsibility, the most frequently. The fact that - as far as integrated thinking and personality features are concerned authors and respondents' indications were convergent is noteworthy. As a consequence, a premise can be made that they are of vital importance for managers. The most numerous group of competences consists of those detailed in literature and, at the same time, perceived as important in at least two out of three studies. These include: knowledge, experience, technical skills, self-development, interpersonal/social skills, focus on clients, communication, decision-making, teambuilding (including motivation), and business competences associated with achieving objectives and results. Only one of the three studies mentions the following skills: teamwork, leadership, and planning and coordinating. However, it may not be a proof of these being the least significant. The situation may originate from difficulties in classification of individual groups, e.g. teamwork is strongly correlated with communication skills, or interpersonal skills in general. Regarding the results of studies featuring teamwork at the bottom of the ladder, importance was placed upon these skills, which may reflect the tangible significance of a more specific competence, i.e. teamwork.

Apart from the above clearly classified competences which are based on the selected typologies, another category labelled "other" was isolated. It contains pursuit of quality, which was categorized in Abraham et al.'s (2001) typology. However, due to the fact that the competence was indicated by a sole author, it was not highlighted as an independent category. Pursuit of quality did not emerge as a significant skill of managers in any of the studies. On the other hand, they indicated two additional ones they deemed significant: information gathering and change management. These two constitute an answer to modern environment organizations operate in. Effective information gathering, its selection and application, offer opportunities for gaining a competitive advantage. In addition, effective change management enables permanent development and flexible adjustment to the ever-changing economic reality.

It is worth mentioning Rakowska and Sitko-Lutek's (2016) survey conducted among specialists from Spain and Taiwan in the scope of key managerial competences of employees of the future. 10 specialists were surveyed from each country. In the question about important present competences, unanimous answer was: social intelligence, relationship and trust building, flexibility, and learning. That confirms the conclusions mentioned above (Rakowska and Sitko-Lutek, 2016, pp. 180-182). 
Pobrane z czasopisma International Journal of Synergy and Research http://ijsr.journals.umcs.pl

Data: 26/04/2023 11:27:17

\begin{tabular}{|c|c|c|c|}
\hline $\begin{array}{l}\text { According to selected } \\
\text { typologies }\end{array}$ & $\begin{array}{l}\text { According to Bakanauskienè } \\
\text { and Martinkienė (2011) }\end{array}$ & $\begin{array}{l}\text { According to Sajgalikova } \\
\text { et al. (2012) }\end{array}$ & $\begin{array}{l}\text { According } \\
\text { to Szczepańska-Woszczyna } \\
\text { and Dacko-Pikiewicz (2014) }\end{array}$ \\
\hline \multirow{2}{*}{$\begin{array}{l}\text { knowledge, experience, } \\
\text { vocational and technical } \\
\text { skills }\end{array}$} & qualification & & \multirow[b]{2}{*}{ knowledge of the industry } \\
\hline & time management & & \\
\hline \multirow{5}{*}{ personality } & responsibility & flexibility & commitment \\
\hline & $\begin{array}{l}\text { awareness of ethics } \\
\text { relevance in business }\end{array}$ & ethical behaviour, support & \\
\hline & fairness & & activity, initiative \\
\hline & $\begin{array}{l}\text { self-confidence (just self- } \\
\text { control) }\end{array}$ & & openness to change \\
\hline & $\begin{array}{l}\text { learning from one's own and } \\
\text { others' experience }\end{array}$ & & \\
\hline \multirow{2}{*}{ self-development } & \multirow{2}{*}{$\begin{array}{l}\text { continuous personal self- } \\
\text { development }\end{array}$} & self-development focus & \\
\hline & & emphasis an awareness & \\
\hline \multirow{4}{*}{ interpersonal/social } & \multirow{4}{*}{$\begin{array}{l}\text { self-trust (ability to trust } \\
\text { others and the work one } \\
\text { performs) }\end{array}$} & empathy & \\
\hline & & respecting others & \\
\hline & & respecting other cultures & \\
\hline & & diversity support & \\
\hline focus on client & focus on client & focus on client & \\
\hline teamwork & & & $\begin{array}{l}\text { ability to listen to and } \\
\text { accept orders }\end{array}$ \\
\hline \multirow{3}{*}{ communication } & communication & \multirow{2}{*}{ feedback } & \\
\hline & convincing communication & & \\
\hline & listening skills & active listening & \\
\hline decision-making & & collective problem solving & creative problem solving \\
\hline \multirow{2}{*}{ leadership } & & & $\begin{array}{l}\text { ability to develop } \\
\text { employees' commitment }\end{array}$ \\
\hline & & & $\begin{array}{l}\text { having the vision and } \\
\text { implementing it }\end{array}$ \\
\hline teambuilding & & empowering & motivating others \\
\hline conflict solving & conflict handling & & \\
\hline planning and coordinating & & & strategic thinking \\
\hline
\end{tabular}

Managerial
Competences
in International
Scope




\section{IJSR} 5

\section{Table2.}

Key managerial competences based on the selected typologies outlined in the literature and results of studies of managers

\begin{tabular}{|c|c|c|c|}
\hline \multirow[t]{2}{*}{ integrate thinking } & \multirow[t]{2}{*}{ analytical thinking } & \multirow[t]{2}{*}{ analytical skills } & $\begin{array}{l}\text { operational and strategic } \\
\text { thinking }\end{array}$ \\
\hline & & & analytical skills \\
\hline image & & & managerial courage \\
\hline \multirow{2}{*}{ business } & \multirow{2}{*}{ striving for results } & & striving to achieve results \\
\hline & & & setting goals \\
\hline \multirow{2}{*}{$\begin{array}{l}\text { other (Abraham et al.: } \\
\text { pursuit of quality) }\end{array}$} & information gathering & openness to information & $\begin{array}{l}\text { observing the market, } \\
\text { competitors }\end{array}$ \\
\hline & & $\begin{array}{l}\text { driving organizational } \\
\text { change }\end{array}$ & coping with change \\
\hline
\end{tabular}

Source: Authors' own study on the basis of the literature.

To sum up, managers' key competences indicated in the literature of the subject and by managers-practitioners in the above-mentioned studies are convergent. Apart from the literature's typologies set of competences, respondents indicated information gathering and change management as particularly important. It results from the necessity for managers to find their place in economic reality and effective use of such. Accumulation of information in managers' job presents a necessity of selecting information which seems valuable from the point of view of a decision-making processes. In addition, technological advancements, dynamic changes and development of markets require managers to adapt swiftly, predict, and, at times, anticipate certain changes in order to create competitive advantage and successfully achieve objectives of the organization.

\section{References}

Abraham, S. E., Karns, L. A., Shaw, K. and Mena, M. A. (2001). Managerial Competencies and the Managerial Performance Appraisal Process, Journal of Management Development., vol. 20 , no. 10 , pp. $842-852$.

Bakanauskiené, I., and Martinkienè, J. (2011). Determining Managerial Competencies of Management Professionals: Business Companies Managers> Approach in Western Lithuania Region, Organizacijų Vadyba: Sisteminiai Tyrimai, no. 60, pp. 29-43.

Boyatzis, R. E. (2011). Managerial and Leadership Competencies, Vision: The Journal of Business Perspective, SAGE Publications, Vol. 15, No. 2, pp. 91-100.

Filipowicz, G. (2016). Zarządzanie kompetencjami perspektywa firmowa i osobista (Competence Management. Organizational and Personal Perspective), WoltersKluwer, Warsaw, pp. 100-101.

Chełpa, S. (2003). Kwalifikacje kadr kierowniczych przedsiębiorstw przemysłowych: kierunki i dynamika zmian (Qualifications of Managers in Industry Enterprises: Directions and Dynamics of Changes), Prace Naukowe Akademii Ekonomicznej we Wroctawiu. Seria: Monografie i Opracowania, No. 996.

Gholipur, R., Mahmoodi, S., Jandaghi, G. and Fardmanesh, H. (2012). Presentation Model of Managerial Competency Approach in Management Development, Interdisciplinary Journal of Contemporary Research in Business, Vol. 3, No. 9, pp. 506-520. 
Kubik, K. (2005). Menedżer w przedsiębiorstwie przyszłości (The Manager in Company of the Future), Towarzystwo Naukowe Organizacji i Kierownictwa „Dom Organizatora”, Torun, pp. 85-86.

Limański, A. (2011). Rola innowacyjności w budowaniu przewagi konkurencyjnej przedsiębiorstwa w gospodarce opartej na wiedzy (The Role of Innovation in Building the Company's Competitive Advantage in the Knowledge-Based Economy), Nierówności Spoleczne a Wzrost Gospodarczy, Vol. 23, pp. 135-147.

Nawrat, D. (2013). Kształtowanie kompetencji innowacyjnych w świetle badań biografii menedżerów (Development of Innovative Competences of Managers in the Light of the Biographical Research), Przedsiębiorczość i zarządzanie, Wydawnictwo SAN, Vol. XIV, No. 4, pp. 36-38.

Penc, J. (2005). Sztuka skutecznego zarzadzania (The Art of Successful Management), Wydawnictwo Oficyna Ekonomiczna, Kraków, pp. 85-86.

Rakowska, A. (2007). Kompetencje menedżerskie kadry kierowniczej we wspótczesnych organizacjach (Management Competences of Management Staff in Contemporary Organizations), Wydawnictwo UMCS, Lublin, pp. 68-69, 72-73.

Rakowska, A. and Sitko-Lutek, A. (2016). Kluczowe kompetencje pracowników przyszłości w opinii ekspertów międzynarodowych - wyniki badań (Key Competences of Future Employees in the Opinion of International Experts - Study), Prace Naukowe Uniwersytetu Ekonomicznego we Wroctawiu, No. 429, pp. 173-185.

Sajgalikova, H., Bajzikova, L., Polakova, M. and Wojcak, E. (2012). Revisiting New Managerial Competences: Is There Enough Motivation to Apply Them?, Procedia - Social and Behavioral Sciences, Vol. 58, pp. 944-952.

Springer, A. (2013). Kompetencje wymagane wobec kierowników zespołów projektowych ocena potencjału pracowników (Competences Required from Managers of Project Teams the Analysis of Employees' Potential), Przedsiębiorczość i zarzadzanie, Wydawnictwo SAN, Vol. XIV, No. 11/ I, p. 198.

Szczepańska-Woszczyna, K. and Dacko-Pikiewicz, Z. (2014). Managerial Competencies and Innovations in the Company - the Case of Enterprises in Poland, Business, Management and Education, Vol. 12, No. 2, pp. 266-282.

Walkowiak, R. (2006). Model kompetencji menedżerów organizacji samorządowych (Competency Model of Local Government Organizations' Managers), Wspótczesne zarzadzanie, No. 2. 